\title{
SYSTEMATIC REVIEW AND COMPARATIVE ANALYSIS OF CURRENT METHODOLOGICAL APPROACH FOR RISK ASSESSMENT OF "OHIS PLANT SKOPJE"
}

\author{
Sandra Kosteska1 ${ }^{1}$ Dragan Gjorgjev² \\ Institute for Accreditation of the Republic of North Macedonia \\ Instutute for Public Health of the Republic of North Macedonia; Faculty of Medicine, Ss. Cyril and Metho- \\ dius University, Skopje, Republic of North Macedonia
}

\begin{abstract}
Citation: Kosteska S, Gjorgjev D. Systematic review and comparative analysis of current methodological approach for risk assessment of "Ohis Plant Skopje". Arch Pub Health 2020; 12 (3). doi. org/10.3889/aph.2020.5654

Key words: health impact assessment, health risk assessment, industrially contaminated sites, epidemiological studies, exposure assessment

*Correspondence: Sandra Kosteska. Institute for Accreditation of the Republic of North Macedonia, Skopje, Republic of North Macedonia. E-mail: sandra.kosteska@iarm.gov.mk

Received: 17-Jul-2020; Revised: 30-Oct-2020; Accepted: 30-Nov-2020; Published: 15-Dec-2020 Copyright: ${ }^{\circledR}$ 2020. Sandra Kosteska,, Dragan Gjorgev.This is an open-access article distributed unde the terms of the Creative Commons Attribution License, which permits unrestricted use, distribu-

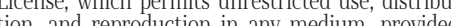
the original author(s) and source are credited. Competing Interests: The author have declared that no competing interests
\end{abstract}

\begin{abstract}
Considering complicity in ecological health and social aspects of industrial contaminated sites (ICSs), the methodologies and approaches of health impact assessments are very heterogeneous. ICSHNet together with WHO recommend two main methodological approaches: health risk assessments and epidemiological studies. Some countries have necessary experience for impact assessment of ICSs, but others have limited resources and less intensity studies. In the Republic of North Macedonia, 16 ICSs are identified, but one of them, lindane dumpsite in OHIS Plant is characterized as the most ecological and public health risk. The general aim: Systematic review of literature data about methodological approaches for health risk assessment of ICSs on international and national level in order to make comparative analysis of current methodological approaches in the Republic of North Macedonia using the case study of ICS OHIS PLANT SKOPJE. Material and methods: The review of scientific and grey literature was performed. The selected scientific studies were searched in the PubMed and Medline databases from 2000-2017, in English and Macedonian. The selected studies and data were analyzed by required information for identification of hazards, exposure assessment and risk characterization. Additionally, the review was performed on published reports of risk assessment of OHIS Plant. Results: A total of 14 original papers were investigated. Continuous monitoring systems for gathering environmental data related to ICSs were used only in two cases and in other studies the concentrations of contaminants in the source were calculated or several ad hoc monitoring campaigns were performed. Exposure assessment was conducted according to qualitative definition for the presence/absence of a source, distance to a source and biomonitoring in the study. Mortality, cancer incidence, congenital abnormalities and hospitalizations were used health data. The study of risk assessment of OHIS Plant has ecological design and indirect quantitative exposure assessment model was used. Conclusion: All investigated studies used three main methodological approaches for exposure assessment: measurement of hazard concentration, distance from source and biomonitoring. Comparable, conducted risk assessment of OHIS Plant follows the recommendations of US EPA and ATSDR with weakness of no existing continual monitoring process and also deficiency of health data and this is the reason for limitation of health impact assessment and setting up EPHT or other public health surveillance system.
\end{abstract}

JАВНО ЗДРАВЈЕ

СИСТЕМАТСКИ ПРЕГЛЕД И КОМПАРАТИВНА АНАЛИЗА
НА ПРИМЕНЕТИОТ МЕТОДОЛОШКИ ПРИСТАП ЗА
ПРОЦЕНКА НА РИЗИЦИТЕ ВО АД ОХИС СКОПЈЕ

Сандра Костеска', Драган Ѓорѓев²

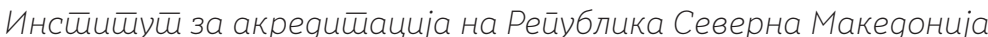

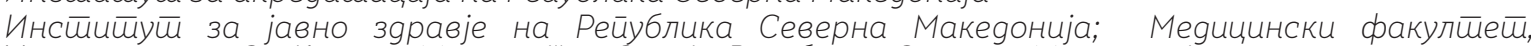

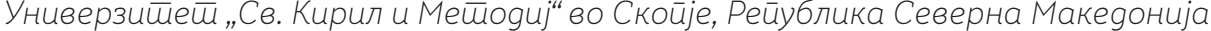

Цитирање: Костеска С, Ѓорѓев Д. Систематски преглед и компаративна анализа на приски прелед и компарапивна анализа на применетио методолошки пристап за проценка на ризицие во АД Охис Скопје. Арх З Здрав 2020;12(3) doi.org/10.3889/aph.2020.5654

Клучни зборови: проценка на влијание врз здравјето, проценка на ризикот врз здравјето, индустриски контаминирани точки, епидемиолошки студии, проценка на експозиција

*Кореспонденција: Сандра Костеска, Ин ститут за акредитација на Република Северна Македонија, Скопје, Република Северна Македонија. E-mail: sandra.kosteska@iarm.gov.mk

\section{Извадок}

Имајќи ја предвид коплексноста во еколошкото здравје и социјалните аспекти на индустриски контаминирани точки (ИКТ), методологијата и пристапот во истражувањето на влијанието на ИКТ врз здравјето се многу хетерогени. ICSHNet во соработка со C3O препорачуваат два главни методолошки приоди за истражување на ИКТ: проценка на здравствениот ризик и епидемиолошки студии. Некои земји го имаат потребното искуство за проценка на влијанието на ИКТ, а некои, пак, имаат лимитирани ресурси и помалку интензивни студии. Во Република Северна Македонија идентификувани се вкупно 16 ИКТ, од кои депонијата со линдан во АД ОХИС Скопје е оценета со највисок еколошки но и јавноздравствен ризик. Основна цел на студијата беше преку преглед на селектирани литературни податоци поврзани со методолошки приоди за проценка на здравствените ризици во индустриски контаминираните точки на меѓународно и национално ниво да се изврши компаративна анализа 
Примено: 17-јул-2020; Ревидирано: 30-окт-2020; Прифатено: 30-ное-2020; Објавено: 15-дек-2020

Печатарски права: 2020 Сандра Костеска, Драган Горѓев. Оваа статија е со отворен пристап дистрибуирана под условите на нелокализирана лиценца, која овозможува неограничена употреба, дистрибуција и репродукција на било кој медиум, доколку се цитиратт оригиналниот(ите) автор(и) и изворот

Конкурентски интереси: Авторот изјавува дека нема конкурентски интереси. на спроведениот методолошки пристап во Република Северна Македонија преку примерот со ИКТ АД ОХИС Скопје. Материјал и методи: Преглед на научна и сива литература, како и селектирање на студии преку базите на податоци PubMed и Medline, изведени во периодот 2000-2017 на англиски и македонски јазик. Селектираната литература и податоци се евалуираа во однос на потребни податоци за идентификација на хазарди, проценка на експозицијата и карактеризацијата на здравствениот ризик. Дополнително, беше извршен преглед на публикувани извештаи од спроведената проценка на ризик на ИКТ АД Охис Скопје. Резултати: Беа анализирани вкупно 14 студии. Континуиран мониторинг систем бил користен само во две студии, а во останатите студии биле пресметувани контаминентите во изворот или биле спроведени краткотрајни мониторинг кампањи. Проценка на експозицијата била спроведена преку одредување на присуството на контаминентот или оддалеченост од изворот и во една студија биомониторингот. Инциденцијата на смртност, појава на канцер и вродени аномалии и број на хоспитализации се користени здравствени податоци. Проценката на ризик на ИКТ АД Охис Скопје по својот дизајн е еколошка студија со примена на индиректна квантитативна проценка на експозицијата. Заклучок: Во сите анализирани студии се применети три главни принципи на проценка на експозицијата: преку одредување на концентрацијата на полутантот, оддалеченоста од изворот и биомониторинг. Споредбено, проценката на ризик на ИКТ АД Охис Скопје методолошки ги следи препораките на US EPA и ATSDR, со слабости во однос на недостаток на континуиран мониторинг систем и недостаток на податоци за здравствениот ефект, што ја лимитира проценката на здравствениот импакт, како и поставување на ЕРНТ или друг систем за јавноздравствен надзор во ИКТ. 


\section{Вовед}

Современиот индустриски развој, покрај придобивките, резултира со бројни штетни ефекти и влијанија врз здравјето на луѓето и животната средина во целост. Големите производствени процеси и индустрии како црната металургија, производството на енергија и петрохемиската индустрија креираат притисоци врз животната средина преку емисии на бројни загадувачки супстанции во медиумите на животната средина. Во многу случаи, контаминентите се ослободуваат од активните индустриски извори (рутински или случајно), или пак се присутни во акумулираниот токсичен отпад од индустриски активности во минатото. Проценките на Европската агенција за животна средина (EEA) за 2011 година се дека во EEA-39 постоеле околу 2.5 милиони потенцијално контаминирани подрачја ${ }^{1}$. Околу една третина од нив (околу 342.000 контаминирани подрачја) се веќе идентификувани и околу 15\% се санирани. Од сите контаминирани подрачја, индустриски контаминираните точки (Indutsrially Contaminated Sites - ИКТ во понатамошниот текст) предизвикуваат голема загриженост од перспектива на јавното здравје, главно поради токсиколошкиот профил на бројните загадувачки супстанции, заради изложеноста што ја доживува локалното население, како и заради потенцијалните здравствени ефекти и влијанија кај населението што живее во тие области ${ }^{1}$. Карактеризацијата на целокупното влијание на ИКТ е комплексна и предизвикувачка задача затоа што честопати се работи за мултипни експозиции на хетерогени опасности и смеси од хемикалии кои афектираат неколку медиуми на животната средина (почва, вода, воздух и синџирот на исхраната); повеќе агенси од повеќе извори, за кои најчесто се претпоставува дека нема да комуницираат меѓусебно; близината на ИКТ до густо населени области, и пред сѐ комплексност која доаѓа од различниот социоекономски контекст и прашања поврзани со нееднаквостите и т.н. еколошка правда (environmental justice) ${ }^{2}$. И кога на ова ќе се надоврзе констатираниот недостаток на веродостојни податоци за изложеноста (експозицијата), повеќеслојната етиологија на повеќето воспоставени асоцијациии, комплексноста на социјалните, економските и факторите поврзани со професионалните експозиции, проценката и карактеризацијата на ризикот претставува сложена задача ${ }^{1}$.

Имајќи ја предвид комплексноста во еколошкото здравје и социјалните аспекти на ИКТ, методологијата и пристапот во истражувањето на влијанието на ИКТ врз здравјето се многу хетерогени. Некои земји го имаат потребното искуство во оваа област, а некои, пак, имаат лимитирани ресурси и помалку интензивни студии. Поголемиот дел од нив ги следат препораките на СЗО во однос на оваа проблематика. СЗО има публикувано неколку документи во кои се опишани специфични прашања поврзани со здравјето на населението и контаминираните подрачја, вклучувајќи ги и стратегиите на комуникација и инволвирање на заинтересираните страни. Во еден од нив се дадени информации, податоци и преглед на моменталниот методолошки пристап за проценка на здравствениот импакт на ИКТ и нивна ремедијација ${ }^{1}$. Од неодамна и ICSHNet Cost Action во соработка со C3O, како резултат на анализа на повеќе студии и искуства од повеќе земји, го публикуваа документот „Guidance on human health impact of industrially contaminated sites" ${ }^{3}$. Целта на овој документ е да обез- 
беди практично упатство за еколошкиот и здравствениот сектор за начинот на разбирање и комуникација на здравствениот импакт на ИКТ. Во него се дадени и насоки за методолошките приоди за проценка на здравствениот ризик во ИКТ. Карактеризацијата на здравствениот импакт на ИКТ е предизвикувачки процес во кој многу елементи треба да се земат предвид ${ }^{4}$. Студиите кои беа опфатени во рамки на анализата на ICSHNet препорачуваат два главни методолошки приоди: проценка на здравствениот ризик и епидемиолошки студии ${ }^{5}$.

Проценката на здравствениот ризик (Human Health Risk AssessmentHHRA) се заснова на квантитативна пресметка на веројатноста да се појави заболувањето, во функција на дозата на експозиција на даден агенс, најчесто хемиска супстанција. Класичната методологија на HHRA која е применета во повеќе студии се заснова на четири чекори6: идентификација на контаминентот, проценка на врската доза-одговор (реакција), проценка на експозицијата и карактеризација на ризикот. Меѓутоа, во повеќе европски земји и САД развиени се детални процедури за проценка на здравствениот ризик'. Американската Агенција за регистрирање на токсични супстанции и болести (US Agency for toxic substances and disease Registry- ATSDR) има развиено посебен концепт за проценка на јавното здравје во кој проценката на здравствениот ризик е надополнета со здравствени податоци за популацијата и вклучува учество на јавноста ${ }^{8}$.

Епидемиолошките студии ја истражуваат врската помеѓу експозицијата и здравствената состојба директно на афектираната популација и преку нив се овозможува: опис на здравствениот профил на населе- нието кое живее во близина на ИКТ со можна поврзаност со локалните еколошки ризик-фактори; анализа на поврзаноста помеѓу еколошката експозиција и здравстевниот исход и причината за негова појава, со цел проверка на претходно поставена хипотеза; како и надзор/контрола на развојниот модел на задравствениот профил на населението. Карактеристичен пример за епидемиолошкиот приод е SENTIERI проектот во Италија (2007-2010), во кој била проучувана поврзаноста на изложеноста на населението кое живее во близина на ИКТ и морбидитетот/болестите и смртноста како резултат на таа изложеност во 18 национални приоритетни контаминирани подрачја 9 .

\section{Важни сегменти при спроведу- вање на HHRA и епидемиолошки- те студии}

Покрај деталниот опис на локацијата, во карактеризацијата на ИКТ важни сегменти се: обезбедување податоци за експозицијата на населението со цел спроведување на проценка на експозицијата и податоци за здравствениот импакт. Првиот сегмент претставува основа за дефинирање на големината на проблемот во насока на идентификување на потенцијално афектираното население, природата и нивото на контаминација ${ }^{10}$. Проценката на експозицијата може да биде квантитативна, која се спроведува преку директно определување на дозата на контаминација (биомони-

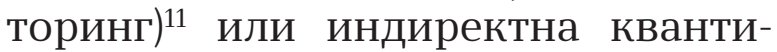
фикација ${ }^{6,8}$, и квалитативна преку поставени индикатори. За карактеризација на здравствениот импакт неопходни се еколошки референтни вредности, односно токсиколошки референтни вредности (TRVs) и здравствени податоци. Достапнос- 
та на здравствените податоци е од есенцијално значење за проценка на здравствениот импакт, особено кога здравствениот мониторинг систем покрива широка палета на здравстени состојби поврзани со различни популациони групи (деца, бремени жени, стари лица, етнички малцинства). Најчесто користени здравствени податоци во епидемиолошките студии се податоците за морбидитет кои се добиваат од болничките бази на податоци, канцер регистрите, предвремено раѓање и вродени аномалии од регистрите за раѓање и податоците за морталитет од националните регистри за морталитет. Многу често, здравствените податоци карактеристични за дадена локација не се лесно достапни или се несоодветни за да ја потврдат поврзаноста со еколошката експозиција.

Податоци за проценка на здравствено-еколошкиот ризик на ИКТ во Република Северна Македонија

Индустриските контаминирани точки во Република Северна Македонија се истражувани во неколку наврати. Несоодветниот третман и управување со отпадот (индустриски, но и комунален) се сметаат за главни извори на контаминација. Проф. Стафилов ја истражувал дисперзијата на тешки метали во различни региони во $\mathrm{Pe}$ публиката ${ }^{12,13}$. Притоа, дисперзијата на отпадните материи делумно или во поголем дел се одвива преку воздухот и резултира во контаминација на почвата, површината но и подземните води, а преку ресуспензија од сувата почва повторно во воздухот. Ова загадување на животната средина секако има влијание и врз изложеноста на хуманата популација со претпоставено сериозни здравствени ризици. Од вкупно 16 контаминирани точки во државата, три се класифицирани како здравствено-еколошки особено опасни ${ }^{14}$. Органско-хемиската индустрија АД ОХИС Скопје и депонијата со линдан во нејзина близина во сите категоризации правени досега е оценета со највисок еколошки, но и јавноздравствен ризик. Од таквиот локалитет постои несомнена опасност од дисперзија на овие хемиски компоненти во сите медиуми на животната средина во непосредна и подалечна околина, а ризикот е уште поголем ако се земе предвид дека депонијата се наоѓa во сред населена зона на град Скопје ${ }^{15}$. Проценката на ризикот која е правена на оваа локација е во рамки на неколку проекти, главно финансирани од UNIDO и EU, за прв пат во 2009 година ${ }^{16}$, а последната е од $2017^{17}$ во рамки на проектот за ремедијација на локацијата.

Анализата на користената методологија и соодветноста на досегашниот пристап и степенот на проценка на јавноздравствениот ризик за АД ОХИС Скопје во споредба со европските пракси е дел од целите на оваа студија.

Целта на трудот беше да се изврши преглед на селектирани литературни податоци поврзани со различните сегменти и методолошки приоди за проценка на здравствените ризици во индустриски контаминираните точки на меѓународно и национално ниво, да се изврши компаративна анализа на спроведениот методолошки пристап за проценка на здравствениот ризик во регистрираните индустриски контаминирани точки во Република Северна Македонија преку примерот со ИКТ АД ОХИС Скопје. 


\section{Материјал и методи}

Ова е студија на пресек која вклучува преглед на научната и сива литература со користење на методот за брз систематски преглед на податоци18. Селектираната литература и податоците се евалуираа на следните подрачја: политики и пракси за управување со јавноздравствени ризици околу ИКТ, анализа на потребни податоци за идентификација на хазарди, проценка на експозицијата и карактеризација на здравствениот ризик. За селекција на податоците и литературата се користеа базите на податоци PubMed и Medline. Фокусот беше ставен на податоци и студии изведени во периодот 2000-2017 на англиски и македонски јазик. Пребарувањето во електронските бази на податоци се изврши со употреба на следниве стандардизирани клучни зборови: проценка на влијание врз здравјето, проценка на ризикот врз здравјето, индустриски контаминирани точки, епидемиолошки студии, проценка на експозција. Со цел да се лимитираат студиите кои се поврзани со влијанието на работната средина и професијата врз здравјето, овие зборови беа наведени како критериуми за исклучување. Во анализа на сивата литература беа користени национални политики, програми, интервенции и проекти кои нудат корисни системски решенија за процена на здравстевните ризици во околина на ИКТ. Географскиот фокус беше ставен на земјите во Европа кои имаат долго искуство со проблемот на ИКТ. Пребарувањето на „сивата литература” опфати пребарување на веб страниците на релевантни меѓународни и национални институции (стручни организации, министерства, академски институции, невладин сектор и сл.), при што со прегледот беа опфатени нивните годишни и технички извештаи, про- екти, евалуациони извештаи и др. За компаративна анализа на применетиот модел во Република Северна Македонија беше извршен преглед на публикувани извештаи од спроведената проценка на ризик на ИКТ АД Охис Скопје, со користење на податоците објавени на интернет страницата на Канцеларијата за неразградливи органски загадувачи POPs во Скопје, www.pops.org.mk. По скринингот на насловот и апстрактот и преглед на комплетниот текст, 14 публикувани изданија беа вклучени во анализата.

\section{Резултати}

Резултатите од анализата на 14 студии, по претходно поставените влезни индикатори, покажаа дека индустриски контаминираните точки покриваат широка палета на хетерогени индустриски активности, кои во најголем дел од студиите биле оперативни повеќе декади пред периодот на истражување. Тие вклучуваат комплексни подрачја, со повеќекратни загадувачки извори (хемиски и петрохемиски индустрии, рафинерии $)^{19-20,26-33}$, до специфични активности, како инценератори ${ }^{23-24,28}$ и депонии од одлагање на отпад ${ }^{17,21-22}$. Во табелата 1 е даден детален приказ на влезните индикатори за секоја поединечна студија. Две студии беа анализирани само во однос на карактеризацијата на ризикот ${ }^{29-30}$.

\section{Собирање на податоци}

Во однос на начинот на собирање на податоците, во само две студии 26,28 бил користен континуиран мониторинг систем, во една студија била користена индиректна квантификација на полутанти ${ }^{27}$, а во останатите студии биле пресметувани контаминентите во изворот или биле спроведени краткотрајни мо- 
ниторинг кампањи $23-24$. Краткотрајни мониторинг кампањи се вршени и на локацијата на ИКТ АД ОХИС17. Најголем дел од примерите се реферираат на исторски податоци од спроведени еколошки мерења на различни медиуми (воздух, почва, земјоделски производи, вода за пиење итн.), но не секогаш се базирале на квалитетни извори на податоци.

\section{Индикатори за проценка на екс- позицијата}

Како индикатори за проценка на експозицијата, во најголем дел била спроведена квантитативна проценка на експозицијата преку одредување на присуството на контаминентот $^{17,}$ 20, 23, 26, 28 или квалитативна (оддалеченост на изворот) $)^{19,} 24,25,27$. Во една епидемиолошка студија бил применет биомониторингот како приод ${ }^{25}$. Во студијата спроведена на ИКТ АД ОХИС Скопје17, проценката на експозиција е квантитативна која опфаќа одредување на концентрацијата на полутантите во почва, површинска вода, земјоделски култури и воздух. Во споредба со студијата од 2009 година, во последната студија во периодот од 2017-2018 е направено ремодулирање на концептот на експозицијата при што попрецизно се одредени патиштата на миграција на контаминентите и идентификувани се дополнителни сценарија на експозиција и експонирани групи (работници, резидентно население, земјоделци).

\section{Здравствени податоци}

Најголем дел од анализираните студии се ретроспективни кохортни студии кои се фокусирани на инциденцијата на смртност, појава на канцер и вродени аномалии (како краен исход од влијанието на ИКТ ${ }^{19,21-23,28}, 4$ студии имаат еколошки дизајн, кои како здравствени податоци ги користеле бројот на хоспитализации или случаи со морбидитет или се базираат само на еколошки параметри ${ }^{20-24}$, како што е и во случајот со ИКТ АД ОХИС Скопје.

Табела 1. Преглед на индикатори за проценка на експозицијата и здравствениот импакт, дизајн на студиите и собирање на податоци кои се користат при проценка на ризик во ИКТ

\begin{tabular}{|c|c|c|c|c|c|}
\hline Локација (Опис) & $\begin{array}{c}\text { Собирање на } \\
\text { податоци }\end{array}$ & $\begin{array}{l}\text { Индикатор за } \\
\text { проценка на } \\
\text { експозиција }\end{array}$ & $\begin{array}{c}\text { Индикатор за } \\
\text { здравствениот } \\
\text { импакт/ } \\
\text { карактеризација } \\
\text { на ризик }\end{array}$ & $\begin{array}{l}\text { Дизајн на } \\
\text { студијата }\end{array}$ & Референци \\
\hline $\begin{array}{l}\text { Индустриска } \\
\text { активност во } \\
\text { минатото }\end{array}$ & $\begin{array}{l}\text { Директен } \\
\text { мониторинг не } \\
\text { е спроведен. } \\
\text { Референци } \\
\text { за историски } \\
\text { податоци за почва } \\
\text { и воздх }\end{array}$ & $\begin{array}{l}\text { Геокодирани } \\
\text { информациии } \\
\text { (податоци за } \\
\text { оддалеченост од } \\
\text { изворот, мерење } \\
\text { на концентрација } \\
\text { на полутантот во } \\
\text { изворот) }\end{array}$ & $\begin{array}{l}\text { Смртност } \\
\text { (рутински собрани } \\
\text { Податоци/канцер } \\
\text { регистри) }\end{array}$ & $\begin{array}{l}\text { Ретроспективна } \\
\text { кохортна }\end{array}$ & Biggeri 2006 (19) \\
\hline $\begin{array}{l}\text { Контаминација на } \\
\text { почва }\end{array}$ & $\begin{array}{l}\text { Мониторинг } \\
\text { на еколошки } \\
\text { податоци, } \\
\text { определување } \\
\text { концентрација на } \\
\text { контаминентот }\end{array}$ & $\begin{array}{l}\text { Проценка на } \\
\text { експозиција преку } \\
\text { определување пат } \\
\text { на експозиција и } \\
\text { дистрибуција на } \\
\text { контаминентот }\end{array}$ & $\begin{array}{l}\text { Определување } \\
\text { на дозата на } \\
\text { експозиција, } \\
\text { карактеризација } \\
\text { на ризикот }\end{array}$ & Еколошка & Brand 2007 (20) \\
\hline $\begin{array}{l}\text { Индустриска } \\
\text { активност } \\
\text { во минатото } \\
\text { поврзана со отпад }\end{array}$ & $\begin{array}{l}\text { Нема податоци } \\
\text { за претходно } \\
\text { спроведен } \\
\text { мониторинг. }\end{array}$ & & & & \\
\hline
\end{tabular}




\begin{tabular}{|c|c|c|c|c|c|}
\hline $\begin{array}{l}\text { Референци за } \\
\text { податоци за } \\
\text { контаминенти во } \\
\text { повеќе медиуми }\end{array}$ & $\begin{array}{l}\text { Геокодирани } \\
\text { информации } \\
\text { од регистри } \\
\text { од ресорните } \\
\text { институции } \\
\text { (недостасувале } \\
\text { податоци за } \\
\text { експозицијата) }\end{array}$ & $\begin{array}{l}\text { Инциденција за } \\
\text { појава на канцер/ } \\
\text { канцер регистри }\end{array}$ & $\begin{array}{l}\text { Ретроспективна } \\
\text { кохортна }\end{array}$ & Pasetto 2013 (21) & \\
\hline $\begin{array}{l}\text { Индустриска } \\
\text { активност } \\
\text { во минатото } \\
\text { поврзана со отпад }\end{array}$ & $\begin{array}{l}\text { Референци } \\
\text { за прецизни } \\
\text { податоци за } \\
\text { полутанти во } \\
\text { гас во почва и } \\
\text { подземна вода }\end{array}$ & $\begin{array}{l}\text { Геокодирани } \\
\text { информации } \\
\text { од регистри } \\
\text { од ресорните } \\
\text { институции }\end{array}$ & $\begin{array}{l}\text { Инциденција за } \\
\text { појава на канцер/ } \\
\text { канцер регистри }\end{array}$ & $\begin{array}{l}\text { Ретроспективна } \\
\text { кохортна }\end{array}$ & Pukkala 2014 (22) \\
\hline $\begin{array}{l}\text { Област во близина } \\
\text { на инценератори }\end{array}$ & $\begin{array}{l}\text { Неколку } \\
\text { спроведени } \\
\text { мониторинг } \\
\text { кампањи за } \\
\text { амбиентен воздух }\end{array}$ & & & & \\
\hline $\begin{array}{l}\text { Метеоролошки } \\
\text { и географски } \\
\text { податоци }\end{array}$ & $\begin{array}{l}\text { Концентрациски } \\
\text { мапи на главните } \\
\text { полутанти }\end{array}$ & $\begin{array}{l}\text { Инциденција за } \\
\text { појава на канцер/ } \\
\text { канцер регистри }\end{array}$ & $\begin{array}{l}\text { Ретроспективна } \\
\text { кохортна }\end{array}$ & Ranzi 2011 (23) & \\
\hline $\begin{array}{l}\text { Активни } \\
\text { инценератори }\end{array}$ & $\begin{array}{l}\text { Студија на } \\
\text { симулација }\end{array}$ & $\begin{array}{l}\text { Оддалеченост од } \\
\text { изворот }\end{array}$ & Нема податок & Еколошка & Cordioli 2013 (24) \\
\hline $\begin{array}{l}\text { Активна хемиска } \\
\text { индустрија }\end{array}$ & $\begin{array}{l}\text { Директно мерење } \\
\text { на концентрација } \\
\text { на 囚-НСН во серум }\end{array}$ & & & & \\
\hline Прашалник & $\begin{array}{l}\text { Оддалеченост од } \\
\text { изворот }\end{array}$ & $\begin{array}{l}\text { Корелација } \\
\text { помеѓу } \\
\text { концентрација на } \\
\text { 囚-НСН во серум } \\
\text { и изворот на } \\
\text { контаминацијата }\end{array}$ & Биомониторинг & Porta 2013 (25) & \\
\hline $\begin{array}{l}\text { Област со повеќе } \\
\text { активни дејности }\end{array}$ & $\begin{array}{l}\text { Континуиран } \\
\text { мониторинг } \\
\text { систем на } \\
\text { полутанти во } \\
\text { амбиентен воздух }\end{array}$ & $\begin{array}{l}\text { Концентрациски } \\
\text { мапи на главните } \\
\text { полутанти }\end{array}$ & $\begin{array}{l}\text { Морбидитет/ } \\
\text { хоспитализации }\end{array}$ & Еколошка & Pascal 2013 (26) \\
\hline $\begin{array}{l}\text { Повеќе ИКТ } \\
\text { со различни } \\
\text { карактеристики }\end{array}$ & $\begin{array}{l}\text { Индиректна } \\
\text { квантификација } \\
\text { на полутанти во } \\
\text { амбиентен воздух }\end{array}$ & $\begin{array}{l}\text { Растојание } \\
\text { од изворот и } \\
\text { потенцијално } \\
\text { афектирано } \\
\text { население }\end{array}$ & $\begin{array}{l}\text { Инциденција на } \\
\text { канцер кај деца }\end{array}$ & $\begin{array}{l}\text { Контролна студија } \\
\text { на случај }\end{array}$ & $\begin{array}{l}\text { Garcia-Perez } 2016 \\
\text { (27) }\end{array}$ \\
\hline $\begin{array}{l}\text { Повеќе области } \\
\text { со активни } \\
\text { инценератори }\end{array}$ & $\begin{array}{l}\text { Континуиран } \\
\text { мониторинг } \\
\text { систем на } \\
\text { полутанти во } \\
\text { амбиентен воздух }\end{array}$ & $\begin{array}{l}\text { Концентрациски } \\
\text { мапи на главните } \\
\text { полутанти }\end{array}$ & $\begin{array}{l}\text { Вродени } \\
\text { аномалии и } \\
\text { проблеми при } \\
\text { раѓање }\end{array}$ & $\begin{array}{l}\text { Ретроспективна } \\
\text { кохортна }\end{array}$ & Candela 2013 (28) \\
\hline $\begin{array}{l}\text { Контаминирани } \\
\text { подрачја со } \\
\text { перзистентни } \\
\text { органски } \\
\text { полутанти (POPs) }\end{array}$ & $\begin{array}{l}\text { Земање } \\
\text { примероци и } \\
\text { одредување } \\
\text { концентрации }\end{array}$ & $\begin{array}{l}\text { Концентрации } \\
\text { во почва, } \\
\text { површинска вода, } \\
\text { воздух, модели на } \\
\text { експозиција }\end{array}$ & $\begin{array}{l}\text { Пресметка на HQ, } \\
\text { ILCR }\end{array}$ & Еколошка & $\begin{array}{l}\text { www.popstoolkit. } \\
\text { com }\end{array}$ \\
\hline $\begin{array}{l}\text { Индустриска } \\
\text { активност } \\
\text { во минатото } \\
\text { поврзана со отпад }\end{array}$ & $\begin{array}{l}\text { Земање } \\
\text { примероци и } \\
\text { одредување } \\
\text { концентрации } \\
\text { на полутантите } \\
\text { од интерес во } \\
\text { неколку ad hoc } \\
\text { кампањи }\end{array}$ & $\begin{array}{l}\text { Концентрации } \\
\text { во почва, } \\
\text { површинска вода, } \\
\text { воздух, зеленчук, } \\
\text { модели на } \\
\text { експозиција }\end{array}$ & $\begin{array}{l}\text { Пресметка на HQ, } \\
\text { ILCR, AAD }\end{array}$ & Еколошка & $\begin{array}{l}\text { Risk Assessment } \\
\text { Analysis Update, } \\
\text { 2019- EMGRISA (17) }\end{array}$ \\
\hline
\end{tabular}




\section{Карактеризација на ризикот}

Во однос на карактеризацијата на ризикот, Davolin cop., ја користеле пресметката на HQ (hazard quotient) $)^{17,29}$, а Ranzi и cop..$^{30}$, бројот на атрибутивни случаи, ACs (attributable cases), при квантитативната проценка на импактот кај експонираната популација, ILCR (Incremental lifetime cancer risk) за проценување на ризикот од експозицијата на канцерогените контаминенти и AAD (Average daily potential dose) за резидентното население кое се хранело со домашен зеленчук (пресметан бил пример за неканцероген ризик за дете) ${ }^{17}$.

\section{Дискусија}

Публикувани се многу студии како и проценки поврзани со влијанието на контаминацијата предизвикана од големи производствени, хемиски, петрохемиски, металуршки и други индустрии, како и рудници вр3 човековото здравје. Објектите за процесирање и одлагање на отпадот од комунално и хазардно потекло се вбројуваат меѓу најчестите примери во Европа во публикуваната литература. Во моментов активните и легални места, вклучително и депозитите на хемикалии, дисконтинуираните депонии, неактивните индустриски капацитети се подложуваат на ретроспективни студии, односно истражувања чијашто цел е проценка на влијанието врз здравјето од минати и сегашни експозиции. Неколку аспекти ги прават овие точки релевантни од јавноздравствен аспект поради фактот што повлекуваат значајни емисии на повеќе различни полутанти во воздухот, почвата, водата и ланецот на исхрана. Локалното население и работниците можат да бидат експонирани на различни начини, преку директен контакт, ингестија или инхалација на токсични агенси, често пати во повеќе различни мешавини и преку индиректни механизми, како што се токсично влијание на екосистемите и пределите или преку пристап во зелените простори и други погодности. Непријатниот мирис, визуелниот ефект, ерозијата и генералната неугледност на овие места исто така имаат влијателна улога. Друго карактеристично обележје на ИКТ е фактот што тие често вклучуваат здравстена нерамноправност. Генерално, овие области се неатрактивни локации за живеење и се населени од популација со низок социоеконмски статус ${ }^{31}$.

Во оваа студија беа анализирани помал број студии, меѓутоа со нив беше опфатена широка палета на индустриски активности во различни земји, различни здравствени исходи, различни периоди на истражување, со што можеше да се обезбеди солиден преглед на типот на еколошките податоци, приодите на експозиција и здравствените податоци кои се неопходни за спроведување на соодветен методолошки приод во истражувањето на ИКТ. Студиите покажуваат дека точната карактеризација на контаминентите е предзивикувачки процес што се должи на комплексноста на самите извори на емисии, кои може да варираат во однос на составот, времето и просторот и да афектираат повеќе различни медиуми. Вкупната експозиција зависи од времето кое популацијата го поминува во различни околини (надворешни, внатрешни, во домот, на работното место), резултирајќи со кумулативна експозиција преку инхалација, ингестија на контаминирана вода или храна и дермален контакт ${ }^{5,24}$. Собирањето на еколошките податоци е важен сегмент од проценката на експозицијата. Континуираното 
собирање податоци најчесто е фокусирано на воздух и мониторинг на квалитетот на водата за пиење, што често пати се изведува само во урбаните населени места и не ги покрива границите на ИКТ каде што е популацијата експонирана ${ }^{32}$. Според тоа, неопходно е постоечката мрежа на мониторинг да биде подобро адаптирана за да може да ја покрие целокупната област на ИКТ, односно не само полутантите во дадената урбана област туку и полутантите поврзани со индустриските активности треба да се земат предвид. И во нашата анализа, само во две студии биле користени рутински податоци од континуиран мониторинг на воздух ${ }^{26,28}$. Голем дел од презентираните примери во студиите даваат оскудна карактеризација на експозицијата и се потпираат на квалитативниот приод кој не може да ја процени комплексноста од интеракцијата на повеќекратните патишта на експозиција и не може да ја увиди разликата од различните нивоа на експозиција. Поради тоа, и самата карактеризација на ризикот е оскудна; резидентното население во студиите е класифицирано како високо или подеднакво експонирано, што можеби ја прави помалку прецизна. Во однос на прибирање здравствени податоци, регистрите за канцер и вродени аномалии и податоци за морбидитет од виталната статистика и хоспитализации од болничките регистри беа користени извори во прегледаните студии. Врската меѓу здравствените податоци од базите на податоци, почнувајќи од матичните лекари, итните служби, хоспитализациите и податоците за смртност на индивидуално ниво, би довело до зголемување на можноста за идентификување на суспектни суппопулации кои се изложени на токсичните ефекти од еколошките хазарди на
ИКТ. Студиите анализирани во ова истражување исто така покажуваат дека постојат потешкотии за прибирање здравствени податоци на индивидуално ниво, поради фактот што заштитата на приватноста на пациентите ја отежнува можноста на истражувачите да ја проценат индивидуалната експозиција на помала географска единица или да ги истражат потенцијалните кофактори како што се: етничкиот и социоекономскиот статус, приходите, возраста итн. Истражувањето во оваа студија покажува дека неколку различни приоди и алатки се достапни за проценка на ризикот во ИКТ, меѓутоа потребно е соодветно да се идентификуваат методолошките пристапи кои имаат капацитет да го проценат комплексната мешавина од еколошки, здравствени и социјални аспекти на ИКТ. Savitiz во својата студија прави анализа во однос на основата за избор на спроведување на HHRA или епидемиолошки студии ${ }^{33}$. Третата опција е епидемиолошки (јавноздравствен) надзор/контрола, која опфаќа собирање, интеграција, анализа и интерпретација на податоците. Надзорот игра важна улога во идентификување на ризичните аспекти и обезбедување информации за ремедијација. Исто така, тој претставува важна алатка за истражување кога не постои сигурен доказ за ризичните ефекти за утврдената полуција или кога податоците и сценариото за експозиција не се достапни во потполност или не се јасни ${ }^{34}$.

Евалуацијата на стратешките пристапи во ремедијацијата на идентификуваните индустриски жешки точки покажува дека активностите во Република Северна Македонија се започнати уште пред 15 години кога се објавени првите физибилити студии на три локалитети: депонијата со НСН изомери во АД 
Охис Скопје, топилницата во Велес и депониите со хром во Силмак и феро јаловината во Макстил35. Од тогаш во неколку наврати посериозно истражување и поставување на соодветни модели за проценка на еколошкиот ризик се правени во АД Охис Скопје, кој беше земен и како пример за споредба во оваа студија. Со додавањето на НСН изомерите на листата на POPs во 2009 година, депонијата со НСН изомери на локацијата ОХИС се препознава како главен проблем со ОСР во Република Северна Македонија. Последните истражувања на терен се направени во периодот 2017-2018 година при што се земени предвид истражувањата на локацијата и моделирањето на еколошкото сценарио од претходните студии во 2006, 2009 и 2010 година. Сите досегашни истражувања се потпомогнати финансиски од EU и UNIDO со вклучување на домашни и надворешни консултантски фирми во чија организација е направено земањето на примероци и нивно тестирање.

Пристапот за справување со еколошкиот ризик на овој локалитет се совпаѓа со дел од заклучоците изнесени во последниот експертски документ подготвен во рамки на ICSHNetCost Action ${ }^{3}$, во кој се дадени клучните приоритети при креирање на политиките кои се однесуваат на влијанието на индустриски контаминираните точки (ИКТ) врз човековото здравје. Анализата направена во споредба со студиите наведени во табелата 1 покажа дека методологијата за проценка на ризикот е индиректна квантитативна проценка на експозицијата (HHRA) која ја препорачуваат меѓународно прифатените упатства на ATSDR и US EPA ${ }^{6,8}$. За таа цел, извршена е проценка на потенцијалната експозиција на утврдените патишта на експозиција, земајќи ги пред- вид различните групи популација и фактори како што се: возраста, однесувањето, работниците во фабриките кои се активни во моментот, земјоделските работници и резидентното население во околината на мапираната локација. Податоците за изворите на контаминација, точките на експозицијата и дизајнот на земање примероци се добиени од деталната карактеризација на самата локација. Важно е да се потенцира дека земањето примероци од почва, површинска вода, воздух и земјоделски култури е направено во неколку ad hoc кампањи, односно нема континуиран мониторинг систем. Податоците од последното анкетно истражување во рамки на земјите членки на ICSHNetCost Action $^{36}$, покажуваат дека во најголем дел од земјите се применува приодот на HHRA, од кој еколошки мониторинг се спроведува во 73\% од земјите. Во однос на податоците поврзани со здравствената состојба, односно за можните несакани ефекти од повеќегодишната експозиција, прегледот на литературата покажа дека до сега не се спроведени епидемиолошки студии во околината на АД ОХИС Скопје за одредување на здравствениот профил на популацијата, па недостатокот на овие податоци ја лимитира проценката на здравствениот импакт. Недостатокот од податоци за морбидитет и морталитет се јавува само кај една третина од земјите учеснички во гореспоменетото анкетно истражување. Карактеризацијата на ризикот од еколошката експозиција во рамки на ИКТ АД Охис Скопје, изразена како HQ (hazard quotient) и ILCR (Incremental lifetime cancer risk), не го изразува типично здравственипт импакт. Shaddick и cop. во една неодамнешна студија ја прикажуваат проценката на можниот здравствен импакт од депониите во 
рамки на Европа ${ }^{37}$, преку пресметување на ACs (attributable cases) и DALYs (disability adjusted years). Унифициран популационен приод за определување на еколошкото оптоварување со болест (EBD) и кај двата приода, епидемиолошко и токсиколошко одредување на врската доза-одговор (реакција) е даден во студијата на Hanninen и сор. ${ }^{38}$. Конкретните истражувања поврзани со националниот систем за контрола во повеќе земји каде што еколошките фактори имаат потенцијален здравствен ефект, го препорачуваат EPHT (Environmental Public Health Tracking) како јавноздравствен надзор во земјите со квалитетен информациски систем и извор на здравствени податоци ${ }^{39}$.

\section{Заклучок}

Резултатите од анализата на 14 студии во ова истражување, по претходно поставените влезни индикатори, покажа дека индустриски контаминираните точки покриваат широка палета на хетерогени индустриски активности, кои во најголем дел од студиите биле оперативни повеќе декади пред периодот на истражување. Тие вклучуваат комплексни подрачја, со повеќекратни загадувачки извори (хемиски и петрохемиски индустрии, рафинерии), до специфични активности, како инценератори и депонии од одлагање на отпад. Во сите нив се применети три главни принципи за проценка на експозицијата: одредување на концентрацијата на полутантот, оддалеченоста од изворот и биомониторинг.

Анализата на спроведената проценка на ризик на ИКТ АД Охис Скопје покажа дека таа методолошки ги следи препораките на US EPA и ATSDR за спроведување на индиректна квантитативна проценка на експозицијата. Како слаба точка треба да се спомене дека земањето примероци од почва, површинска вода, воздух и земјоделски култури и нивно тестирање е направено во неколку ad hoc кампањи, односно нема континуиран мониторинг систем. Втората слабост е недостатокот на податоци за здравствениот ефект, што ја лимитира проценката на здравствениот импакт, како и поставување на ЕРНТ или друг систем за јавноздравствен надзор во ИКТ.

\section{Референци}

1. WHO. Contaminated sites and health. Reports of two workshops, 2011, Siracuse, Itali, 18 November 2011, Catania, Italy, 21-22 June 2012, Copenhagen WHO Regional Office for Europe, 2013.

2. Lavarone I. Industrially Contaminated Sites and Health Network. First Plenary Conference. Industrially Contaminated Sites and Health Network (ICSHNet, COST Action IS1408). Istituto Superiore di Sanità. Rome, October 1-2, 2015.

3. Guidance on human health impact of industrially contaminated sites. Joint COST Action ad WHO Report. ICSNET Network COST Action. Edited by: Ivano Lavarone and Marco Martuzzi, (http://www.icshnet. eu/wp-content/uploads/2019/05/ WHO-COST-Action-Guidance-Document.pdf, пристапено во март 2020.)

4. Lavarone I, Pasetto R. ICSHNet. Environmental health challenges from industrial contamination. Epidemiol Prev 2018;42(5-6) Suppl1:5-7.

5. Pasetto R, Martin-Olmedo P, Martuzzi M, Iavarone I. Exploring available options in characterising the health impact of industrially contaminated sites. Ann Ist Super Sanita 2016;52(4):476-82.

6. US EPA Guidelines for $\mathrm{Hu}^{-}$ man Exposure Assessments. 
EPA/100/B-19/001.2016, Updated 2019. (https://www.epa.gov/sites/ production/files/2020-1/documents/guidelines_for_human_exposure_assessment_final2019.pdf, во март 2020)

7. Swartjes FA. Human health risk assessment related to contaminated land: state of the art. Environ Geochem Health 2015;37(4):651-73.

8. Agency for Toxic Substances and Disease Registry. Public Health Assessment Guidance Manual (2005 Update). Достапно на: https:// www.atsdr.cdc.gov/hac/phaman$\mathrm{ual} / \mathrm{pdfs} / \mathrm{phagm}$ _final1-27-05.pdf. Пристапено во март 2020.)

9. Crocetti E, Pirastu R, et al. SENTIERI Project: results. Epidemiol Prev 2014; 38 (2) Suppl. 1: 29-124. Достапно на: https://www.ncbi. nlm.nih.gov/pubmed/24986500. Пристапено во март, 2020.

10. IPCS. IPCS risk assessment terminology. Part 1: IPCS/OECD key generic terms used in chemical hazard/risk assessment; Part 2: IPCS glossary of key exposure assessment terminology. Geneva, World Health Organization, International Programme on Chemical Safety (Harmonization Project Document 1), 2004.

11. Albertini R, Bird M, Doerrer N, Needham L, Robison S, Sheldon L, Zenick H. The use of biomonitoring data in exposure and human health risk assessments. Environ Health Perspect 2006;114(11):1755-62.

12. Stafilov T, Peeva L, Nikov B, De Koning A. Industrial hazardous waste in the Republic of Macedonia. Applied Environmental Geochemistry - Anthropogenic İmpact on Human Environment in the SE Europe, Ljubljana, Proceedings Book (ŠAJN, R., ŽİBERT, G. \& ALİJAGíĆ, J., (Eds.)), 2009, ISBN 978-961-6498-18-0, 108112.

13. Stafilov T. Environmental pollution with heavy metals in the Republic of Macedonia.- Contributions, Section of Natural, Mathematical and Biotechnical Sciences, MASA, 2014, 35/2, 81-119.

14. Bloemen JThH. Biomonitoring of Macedonia. Report of Twinning Project MK 12 IB EN 01- Further strengthening the capacities for effective implementation of the acquis in the field of air quality 2016, 20 стр; Report No. 1.

15. Industrial Contaminated Sites ("hotspots") National Waste Management Plan and Feasibility Studies. Contract No.: 01/MAC05/05/002. Ref. No.: EUROPEAID/115138/D/SV/ MK.

16. Old environmentalburdens in chemical plant Ohis, Skopje, Updated risk assessments, November 2009, Project of Development Cooperation of the Czech Republic and Macedonia, ENACON. http://pops.org.mk/wpcontent/uploads/2020/03/Macedonia_OHIS_URA_report_final_2009. pdf. Пристапено во март 2020.

17. Removal of technical and economic barriers to initiating the clean-up activities for alpha- $\mathrm{HCH}$, beta-HCH and lindane contaminated sites at Ohis Project ID 100122 - Risk Assessment Analysis Update, 2019EMGRISA, http://pops.org.mk/ wp-content/uploads/2020/03/RiskAssessment-Analysis-Update-final. pdf, пристапено во март 2020.

18. Ganann R, Ciliska D, Thomas $H$. Expedityng systematic reviews: method and implications of rapid reviews. Implementation Science 2010; 5:56.

19. Biggeri A, Lagazio C, Catelan D, Pirastu R, Casson F, Terracini B. Report on health status of residents in areas with industrial, mining or military sites in Sardinia, Italy. Epidemiol Prev 2006;30(1) Suppl 1:5-95.

20. Brand E, Otte PF, Lijzen JPA. CSOIL 2000: an exposure model for human risk assessment of soil contamination. A model description. 
RIVM report 711701054/2007. 2007. Available from:https://www.rivm. nl/dsresource?objectid=b13004132fb6-4c18 a38332c921f6e592\&type= org\&disposition=inline

21. Pasetto R, Ranzi A, Togni A, et al. Cohort study of residents of a district with soil and groundwater industrial waste contamination. Ann Ist Super Sanita 2013; 49(4):354-57.

22. Pukkala E. A follow-up of cancer incidence among former Finnish dump site residents: 19992011. Int J Occup Environ Health 2014;20(4):313-17.

23. Ranzi A, Fano V, Erspamer L, Lauriola P, Perucci CA, Forastiere F. Mortality and morbidity among people living close to incinerators: a cohort study based on dispersion modeling for exposure assessment. Environ Health 2011;10:22.

24. Cordioli M, Ranzi A, De Leo GA, Lauriola P. A review of exposure assessment methods in epidemiological studies on incinerators. J Environ Public Health 2013; 2013:129470.

25. Porta et. Al. A biomonitoring study on blood levels of beta-hexachlorocyclohexane among people living close to an industrial area. Environmental health 2013,12:57.

26. Pascal L, Pascal M, Stempfelet M, Goria S, Declercq C. Ecological study on hospitalizations for cancer, cardiovascular, and respiratory diseases in the industrial area of Etang-de-Berre in the South of France. J Environ Public Health 2013;2013:328737.

27. García-Pérez J, Morales-Piga A, Gómez-Barroso D, et al. Residential proximity to environmental pollution sources and risk of rare tumors in children. Environ Res 2016;151:265-74.

28. Candela S, Ranzi A, Bonvicini L, et al. Air pollution from incinerators and reproductive outcomes: a multisite study. Epidemiology 2013;24(6):86370.
29. Davoli E, Fattore E, Paiano V, et al. Waste management health risk assessment: a case study of a solid waste landfill in South Italy. Waste Manag 2010;30(8-9):1608-13.

30. Ranzi A, Ancona C, Angelini P, et al. Health impact assessment of policies for municipal solid waste management: findings of the SESPIR Project. Epidemiol Prev 2014;38(5):313-22.

31. World Health Organization. Environment and health risks: a review of the influence and effects of social inequalities. Copenhagen: WHO Regional Office for Europe; 2010.

32. Pascal M, Pascal L, Bidondo ML, et al. A review of the epidemiological methods used to investigate the health impacts of air pollution around major industrial areas. J Environ Public Health 2013;2013:737926.

33. Savitz D. When is epidemiological research a helpful response to industrial contamination? Epidemiol Prev 2018;42(5-6) Suppl 2:89-92.

34. Martin-Olmedo P, Hams R, Santoro $\mathrm{M}$, et al. Environmental and health data needed to develop national surveillance systems in industrially contaminated sites. Epidemiol Prev 2018;42 (5-6) Suppl1:11-20.

35. http://pops.org.mk/wp-content/uploads/2020/03/CARDS-2006_FEASIBILITY-STUDY_Volume-I_OHISPlant.pdf, пристапено во март 2020.

36. Martin-Olmedo P, Sánchez-Cantalejo C, Ancona C, Ranzi A, Bauleo L, Fletcher T et al.Industrial contaminated sites and health: results of a European survey. Epidemiol Prev 2019; 43 (4):238-248.

37. Shaddick G, Ranzi A, Thomas ML, Aguirre-Perez R, Dunbar BekkerNielsen M, Parmagnani, F et al. Towards an assessment of the health impact of industrially contaminated sites: Waste landfills in Europe. Epidemiol Prev 2018, 42, 69-75. 
38. Hänninen $\mathrm{O}$, Knol AB, Jantunen $M$, et al. Environmental burden of disease in Europe: assessing nine risk factors in six countries. Environ Health Perspect 2014;122(5):439-46.

39. Martin-Olmedo P, Hams R, Santoro M, Ranzi A, Hoek G, de Hoogh K et al. Environmental and health data needed to develop national surveillance systems in industrially contaminated sites. Epidemiol Prev 2018, 42, 11-20. 